\title{
RETRACTED ARTICLE
}

\section{Snail Consumption Pattern in Ibarapa Central Local Government of Oyo State, Nigeria}

\section{${ }^{1}$ BABATUNDE, TO; ${ }^{2}$ BABATUNDE, OO; ${ }^{3}$ ADULOJU, AR; ${ }^{4}$ OLUWALANA, T}

\author{
${ }^{*}$ Department of Forestry Technology, Federal College of Forestry Jericho Ibadan, Oyo State Nigeria \\ ${ }^{2}$ Department of Wood and Paper Technology, Federal College of Forestry Jericho Ibadan, Oyo State Nigeria \\ ${ }^{3}$ Department of Agricultural Technology, Federal College of Forestry Jericho Ibadan, Oyo State, Nigeria \\ ${ }^{4}$ Department of Basics and General Studies Federal College of Forestry Jericho, Ibadan, Oyo State, Nigeria \\ *Corresponding Author Email: sollybee2012@gmail.com; Tel: +2348033948859
}

\begin{abstract}
Snails are very high in nutrients such as proteins, iron, and water, while being low in fat, therefore its consumption is popular in various countries around the globe and humane been consuming snails for thousands of years. The objective of this paper is to evaluate the snail consumption, pattern in Ibarapa Central Local Government Area of Oyo state Nigeria using standard structured questionnaize techniques and analyzing the data by descriptive statistics and multiple regression technique. Theresult showed Yajority of respondents $(56.6 \%)$ were female, result showed that $44.4 \%$ of the respondents' were between the age of $31-40$ and $59.6 \%$ were married and $53.5 \%$ of the household have the largest size. Also the result obtaine from this study shows that Christian was dominant (55.6\%) that consumed snail meat, this indicate that there is making snail meat more demanded in the study trea. The result shows that snail meat prevent blood pressure, also Regression result showed that Age and heałpendition increases the rate at which snail is consumed in the study Area. Based on this result it is revealed that income, Taste, Price, Availability and Accessibility were the factor affecting snail consumption pattern in the study Area.
\end{abstract}

THIS ARTICLE HAS BEEN RETRACTED: This article has been retracted at the request of the Authors. The authors made multiple submissions and all part of the paper had already appeared in Journal of Applied Sciences \& Environmental Management, 24(6), 1103-1108 (2020), with DOI: https://dx.doi.org/10.4314/jasem.v24i6.25 and labeled on AJOL as https://www.ajol.info/index.php/jasem/article/view/197692. One of the conditions of submission of a paper for publication in JASEM is that authors should declare explicitly that their work is original and has not been submitted or appeared in a publication elsewhere. As such this article re-presents a severe misuse of the scientific publishing system. The scientific community takes a very strong view on this matter and apologies are offered to readers of the journal that this was not detected during the submission process.

\section{DOI: https://dx.doi.org/10.4314/jasem.v24i6.25}

Copyright: Copyright (C) 2020 Babatunde et al. This is an open access article distributed under the Creative Commons Attribution License (CCL), which permits unrestricted use, distribution, and reproduction in any medium, provided the original work is properly cited.

Dates: Received: 19 April 2020; Revised: 22 May 2020; Accepted: 21 June 2020

Keywords: Heliculture, Archachatina marginata, Achatina achatina, snail consumption pattern

Heliculture is the science and occupation of raising snails; and there is a growing interest in the rearing of snail for meat and for sale in Africa and in Nigeria in particular (Omole, 2001), (Kehinde, 2009). The commonest breed of African snails in the Archatina marginata and Achatina achatina. Achatina achatina grows exceptionally large and the adult has been known to be consistently bigger than the average sized Archachatina fulica species. The very large snails are kept as pets in the Western world, where owners prize their large size, distinctive marking and rarity (Pet, 2007). It is considered a potentially serious pest, an invasive species. The snails have already established themselves in the wild in Florida, where they are considered a pest (Babara, 2013). Snail meat is highly nutritious containing $37.5 \%$ protein (on DM basis); has high iron content ( 45 to $59 \mathrm{mg} / \mathrm{kg}$ ) and low sodium $(2.32 \mathrm{~g} / 100 \mathrm{~g})$ and fat $(0.05-0.08 \%)$ contents (Sogbesan and Ugwumba, 2008). The meat is low in cholesterol and a source of vital minerals required for normal tissue development and maintenance; and it is an ideal meat for diabetics and those with vascular disease such as heart attack, cardiac arrest, hypertension and stroke (Funmilayo, 2008). Some ethnic groups even have superstitious beliefs that discourage the eating of snail meat or eating certain species of snail to the detriment of others (Malik, et al., 2011). Food and Agriculture Organization (FAO 1989) has reported that the 
average animal protein intake in Nigeria is low, calling for concerted efforts towards alleviating this crisis of protein shortage. Unfortunately, the conventional and regular sources of animal protein in the country like beef, pork, goat meat, fish, poultry etc are getting out of the reach of common populace, due to their high price, as a result of the economic down-turn (Olayide, 2004). Also, Wufueke (2004) reported that the consumption of animal protein in Nigeria is $5.5 \mathrm{~g}$ per head per day which is absolutely below the Food and Agriculture Organization recommendation of $35 \mathrm{~g}$ per head per day. To bridge this gap, various nonconventional animal protein sources like snail, cricket, and winged termites are now being explored. Snail meat is reported to be high in protein, low in fat, and a good source of ion (Ademolu et al, 2004). Though snails are gathered from the forest, they are also produced through snail farming (heliculture) Snails as human food have been known since Roman times. In the middle ages, they were loved as some food rich in protein (Agbelusi and Ejide, 1992). Cobbinah (1993) reported that snails are gathered in the wild, packed into bags, wooden crates or basket and transported to main roads or to urban centres as a source of income. The edible portion (foot) of $A$. marginata, contained 17 - 18\% crude protein (Odukoya, 1998, Omole, 1999), which compares to conventional livestock meat like Multon, Duck and Chicken, which have crude protein content of $16.9,18.6$ and $20.5 \%$ respectively (FAO, 2013). The fat content of snail meat ranged between 0.96 - 1.36\% (Odukoya, 1998; Bright, 1999), which is very low, when compared to 9.6, 21.4 and $23.0 \%$, found in chicken egg, Multon and Duck products respectively. The low fat content makes snail meat a good antidote for the hypertensive patient and those that have fat related diseases (Bright, 1999). The iron content ranges between 2.7 and $3.5 \mathrm{mg} / 100 \mathrm{~g}$ (Imevbore and Ademosun, 1988), while chicken egg, multon and duck have 1.6, 2.0 and $1.08 \mathrm{mg} / 100 \mathrm{~g}$ respectively (FAO, 2013), hence it is good for curing anaemia.

In traditional African medicine, snail meat is used in the preparation of concoctions for the treatment of various cases such as reduction of labour pains and blood loss in pregnant women during delivery.. Snail farming is becoming a very popular vocation, due to its embracement as an empowerment and job creation avenue by the Federal Government of Nigeria (Oropo et al, 2019), (Akinnusi et al 2018) It has been adjudged as a self-sustaining business, requiring small capital, land and other logistics, with resultant job creation potentials, along its value chain; for collectors, farmers, marketers, and research scientists (Akinnusi et al, 2018and Adeniyi et al, 2013).

The nutritional benefit of snail meat cannot be overemphasized because it offers all the amino acids required by man (Adeyeye, 1996). Snail meat is high in protein, iron, and low in fat (Agbogidi et al., 2008). Snail consumption has increased in Africa due to more people avoiding red meat for meat for health reasons (omole et. al., 2006). (Kehinde et al 2019) Unlike other extinction-prone wild animals that attract public or government intervention, the Giant African Snail (GAS) has received little to no intervention; if measure like snail farming are not promoted, the GAS may disappear from our forest. The objective of this paper is to evaluate the snail consumption pattern in Ibarapa Central Local Government Area of Oyo state Nigeria the socio-economic activities of snail rearing and it relative consumption pattern among people of Ibarapa local government, to provide reliable statistics and to stimulate further studies on it.

\section{MATERIALS AND METHODS}

Area of study:The study was conducted in Ibarapa Central Local Government area of Oyo state. Ibarapa Central Local Government is made up of two major towns which are; Igboora and Idere. Igboora consists of seven quarters (Igbole, Pako, Iberekodo, Sagan-un, isale-oba, Okesherin and Idofin.) while Idere consists of three quarters which are; Koso, Malete, and Okeoba. The study area has human population of about 102,979 according to 2006 population census (NPC 2006). The major occupation of the people in this area is mainly agriculturally based (most of them are farmers) while other secondary income generating activities in the area include: Trading, Hunting, Blacksmithing, Teaching, weaving, Tailoring, Carpentry, etc. There are two main planting season in the local government and these are the dry and wet season. The dry season usually occurs between the month of November to March while the wet season occurs between the month of April and October. (Kirchhoff, etal, 2007).

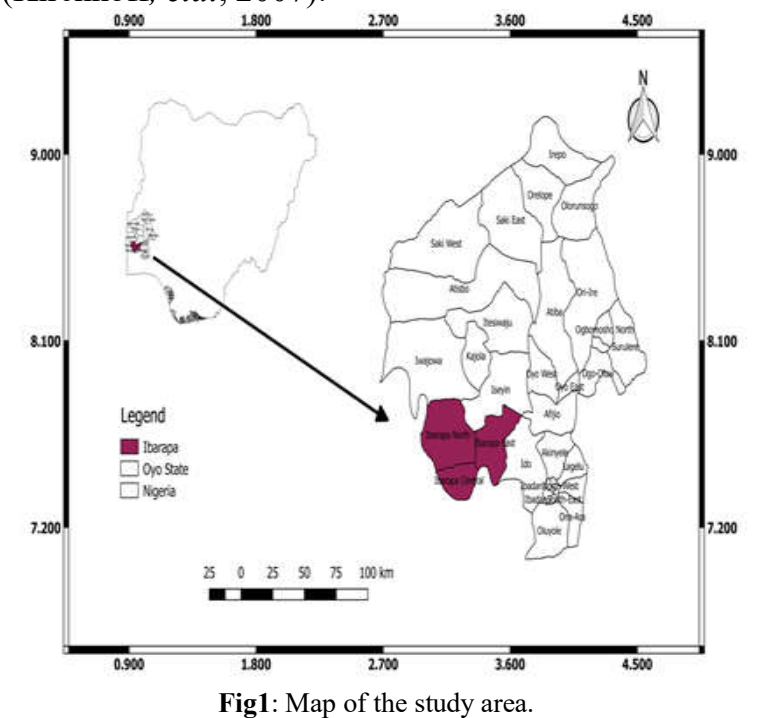


The major crop being cultivated in the local government are yam, maize, cassava, cashew, cocoa, citrus and so on. The largest percentage of people in this part of the country are Yorubas though there exists other tribes like the Fulanis and the Hausas. (Hackett, et al 1988) The study area shares boundary relative with Ibarapa North Local Government Area in the North, Abeokuta Ogun State in the South and Ibarapa East and Benin Republic in the West and East respectively. The rainfall pattern of the area follows a tropical type with an average annual rainfall ranging from $1000 \mathrm{~mm}$ to $1430 \mathrm{~mm}$ and fairly high temperature. This also gives the area the opportunity to have two farming planting season. The vegetation of the area is largely rainforest and savannah and this makes it possible to cultivate a wide array of crops ranging from tree crops to arable crops and rearing of different livestock.

Sampling Size: A multistage sampling was used in this study to sampled One hundred (100) respondents that formed the sample used.

Sample procedure: Firstly, a systematic random sampling were used to select five (5) residential house at interval of twenty (20) from each ward (igbole, pako, iberekedo, koso and malete) respectively in the study area.Secondly, twenty respondents were randomly selected in the village, one household from each residential house, hence a total number of One hundred (100) respondents to which structured questionnaire were administered.

Types of Data and Instrument of Data Collection: Primary and secondary data were used for the study.. The questionnaires were used to obtain data on socioeconomic characteristics of the sampled household as well as household expenditure on snail meat.

Method of Data Analysis: Data obtained was analyzed using descriptive statistics and multiple regression technique.

Five (5) Point Likert Scale Rating Technique.

$$
X_{w}=\frac{\sum_{j=1}^{5} n i(5 i)}{n}
$$

Where $\mathrm{Xw}=$ Weighted Mean Score; $\mathrm{n}=$ Number of respondents.

Note: The scale was in the following range of means; a. below: $2.95=$ Not Serious (NS); b. between: $2.95-$ $3.05=$ Serious $(\mathrm{S})$; c. above: $3.05=$ Very Serious $(\mathrm{VS})$
Within the context of this study, a snail consumption model is implicitly stated as:

$$
\mathrm{C}=\mathrm{f}\left(\mathrm{X}_{1}, \mathrm{X}_{2}, \mathrm{X}_{3}, \mathrm{X}_{4}, \mathrm{X}_{5}, \mathrm{X}_{6}, \mathrm{e}\right)
$$

Where $\mathrm{C}=$ Rate of snail meat consumption; $\mathrm{X}_{1}=$ Family size; $\mathrm{X}_{2}=$ Level of education; $\mathrm{X}_{3}=$ Religion; $\mathrm{X}_{4}=$ Age

$\mathrm{X}_{5}=$ Price of substitutes; $\mathrm{e}=$ Error term.

\section{RESULTS AND DISCUSSIONS}

From the result obtained, it was revealed that $56.6 \%$ of the respondents were female while $43.4 \%$ were male which implies that snail consumers were dominated by female in the study area. This result also shows that $44.4 \%$ of the snail consumers fall between $31-40$ years of age, implies that, in the study area, snail consuming is done by active and energetic people in the middle ages.

\begin{tabular}{|c|c|c|}
\hline Variable & Frequency & Percentage \\
\hline \multicolumn{3}{|l|}{ Gender } \\
\hline Male & 43 & 43.4 \\
\hline Female & 56 & 56.6 \\
\hline Total & 99 & 100 \\
\hline \multicolumn{3}{|l|}{ Age } \\
\hline $11-20$ & 7 & 7.1 \\
\hline $21-30$ & 30 & 30.3 \\
\hline $31-40$ & 44 & 44.4 \\
\hline 40 above & 18 & 18.2 \\
\hline Total & 99 & 100 \\
\hline \multicolumn{3}{|l|}{ Marital Status } \\
\hline Single & 20 & 20.2 \\
\hline Married & 59 & 59.6 \\
\hline Divorce & 16 & 16.2 \\
\hline Widow/widower & 4 & 4.0 \\
\hline Total & 99 & 100 \\
\hline \multicolumn{3}{|l|}{ Household size } \\
\hline 1 & 1 & 1.0 \\
\hline $2-3$ & 53 & 53.5 \\
\hline $4-7$ & 42 & 42.4 \\
\hline Above 8 & 3 & 3.0 \\
\hline Total & 99 & 100 \\
\hline \multicolumn{3}{|l|}{ Educational qualification } \\
\hline No formal education & 18 & 18.2 \\
\hline Primary education & 32 & 32.3 \\
\hline Secondary education & 34 & 34.3 \\
\hline National diploma & 15 & 15.2 \\
\hline Total & 99 & 100 \\
\hline \multicolumn{3}{|l|}{ Occupation } \\
\hline Farming & 28 & 28.3 \\
\hline Civil servant & 20 & 20.2 \\
\hline Business & 30 & 30.3 \\
\hline Others & 21 & 21.2 \\
\hline Total & 99 & 100 \\
\hline \multicolumn{3}{|l|}{ Religion } \\
\hline Christian & 55 & 55.6 \\
\hline Muslim & 44 & 44.4 \\
\hline Total & 99 & 100 \\
\hline \multicolumn{3}{|l|}{ Snail you prefer eating } \\
\hline Archachatinamarginata & 55 & 55.6 \\
\hline Archatinaarchatina & 44 & 44.4 \\
\hline
\end{tabular}

Table 1.Socio economic characteristics of the respondents 
The result further shows that $59.6 \%$ of the respondents were married, this implies that majority of the respondents could have a larger number of the family which could be useful for consuming activities. It also shows that $53.5 \%$ had household size $1-3,42.4 \%$ had $4-7,1.0 \%$ had 0 while remaining $3.1 \%$ had above 8 respectively. This implies that the more number in the household the more the consumption level with the corresponding increase in income. It also shows that $34.3 \%$ of the respondents attended secondary school education, $18.2 \%$ has no formal education, $32.3 \%$ and $15.2 \%$ attended primary school and national diploma respectively in the study area, which implies literacy in the study area is still relatively low. More over the table 1 shows that $30.3 \%$ were self-employed while $28.3 \%, 21.2 \%$ and $20.2 \%$ were farming, others and civil servant. The result also shows that both Christian and Muslim were $56.6 \%$ and $44.4 \%$ while $11.1 \%$ were Tradition in the household of the study area. Lastly it also shows that $55.6 \%$ of the respondents preferred eating Archachatina marginata while the remaining 44.4\% preferred eating Archatina archatina. The table shows that $43.4 \%$ of the respondents agree that snail consumption reduce obesity while $1.0 \%, 6.1 \%, 13.1 \%$ and $36.4 \%$ were strongly disagree, disagree, undecided and strongly agree respectively in the study area. Furthermore in table 2, also indicate that 35.4\% of the respondents were strongly agree that snail consumption helps in curing cancer while 31.3\%, $29.3 \%$ and $4.0 \%$ of the respondents agree, undecided and disagree respectively in the study area. It also revealed that $57.6 \%$ of the respondents were strongly agree that the snail consumption is good to prevent blood pressure while $31.3 \%$ and $11.1 \%$ where disagree and undecided. Lastly, the result also shows that $53.5 \%$ of the respondents agree the snail consumption have nutritional value while the other $4.0 \%, 12.1 \%$ and $30.3 \%$ of the respondents were disagree, undecided and strongly disagree.

Table 2: The health benefits of snail consumption in the study area

\begin{tabular}{lllllllll}
\hline variable & SA & A & UN & D & SD & Mean & Rank & Remark \\
\hline Snail meat reduce obesity & $13(13.1)$ & $43(43.4)$ & $37(36.7)$ & $6(6.1)$ & $1(1.0)$ & 2.39 & 2 & NS \\
Snail meat cure cancer & $35(35.4)$ & $31(31.3)$ & $29(29.3)$ & $4(4.0)$ & $0(0.0)$ & 2.02 & 4 & NS \\
It prevent blood pressure & $57(57.6)$ & $0(0)$ & $11(11.1)$ & $31(31.3)$ & $0(0)$ & 2.16 & 3 & NS \\
It helps in nutritional value & $0(0)$ & $54(53.5)$ & $12(12.1)$ & $4(4.0)$ & $30(30.3)$ & 3.10 & 1 & VS \\
\hline
\end{tabular}

Field survey, 2019; Percentage in parenthesis; Not Serious (NS), Very Serious (VS)

Key: $S A=$ Strongly Agree, $A=$ Agree $U N=$ Undecided $D=$ Disagree $S D=$ Strongly Disagree

Table 3: The attitude and interest toward snail consumption in the study area

\begin{tabular}{lllllllll}
\multicolumn{10}{c}{ Table 3: The attitude and interest toward snail consumption in the study area } \\
\hline Variable & SA & A & UN & D & SD & Mean & Rank & Remark \\
\hline Prefer eating than rearing & $0(0.0)$ & $31(31.3)$ & $45(45.5)$ & $16(16.2)$ & $7(7.1)$ & 2.99 & 4 & S \\
Rearing than eating(size) & $0(0.0)$ & $22(22.2)$ & $45(45.5)$ & $16(16.2)$ & $7(7.1)$ & 3.09 & 3 & VS \\
Prefer eating and rearing & $0(0.0)$ & $39(39.9)$ & $42(42.4)$ & $14(14.1)$ & $4(4.0)$ & 2.83 & 5 & NS \\
Not eating and not rearing & $0(0.0)$ & $11(11.1)$ & $13(13.1)$ & $30(30.3)$ & $45(45.5)$ & 4.10 & 1 & VS \\
Eating snail as whole meat & $0(0.0)$ & $11(11.1)$ & $11(11.1)$ & $50(50.5)$ & $25(25.3)$ & 3.92 & 2 & VS \\
\hline \multicolumn{7}{c}{ Field survey, 2019; Percentage in parenthesis; Not Serious (NS), Serious (S), Very Serious (VS) }
\end{tabular}

Table 4: The constraints facing snail consumers in the study area

\begin{tabular}{lllllllll}
\hline Variable & SA & A & UN & D & SD & Mean & Rank & Remark \\
\hline Income determinant & $17(17)$ & $45(45.5)$ & $19(19.2)$ & $11(11.1)$ & $7(7.1)$ & 2.45 & 5 & NS \\
Unable to afford the price & $13(13.1)$ & $22(22.2)$ & $33(33.3)$ & $25(25.3)$ & $6(6.1)$ & 2.89 & 4 & NS \\
Taste affection & $14(14.1)$ & $24(24.2)$ & $19(19.2)$ & $21(21.2)$ & $21(21.2)$ & 3.11 & 3 & VS \\
Is not readily available & $0(0.0)$ & $0(0.0)$ & $6(6.1)$ & $36(36.4)$ & $57(57.6)$ & 4.52 & 1 & VS \\
Religion permit & $5(5.1)$ & $1(1.0)$ & $5(5.1)$ & $36(36.4)$ & $52(52.5)$ & 4.30 & 2 & VS \\
\hline
\end{tabular}

Field survey, 2019; Percentage in parenthesis; Not Serious (NS), Very Serious (VS)

Key: $S A=$ Strongly Agree $A=$ Agree $U N=$ Undecided $D=$ disagree $S D=$ Strongly Disagree

It revealed that $45.5 \%$ of the respondents in the study area undecided that they prefer eating snail than rearing snail, the result further shows that $45.5 \%$ of the respondents also undecided that they prefer rearing than eating snail due to it size while $12.1,20.2 \& 22.2$ strongly disagree, disagree and agree respectively in the study area. The result also revealed that $42.4 \%$ of the respondent undecided that they prefer both eating and rearing of snail in the study area. Furthermore, $45.5 \%$ of the respondents strongly disagree that they do not prefer both rearing and eating of snail. Lastly, the result shows that $50.5 \%$ of the respondents disagree that they eat snail as whole meat while $25.3 \%$, $11.1 \%$ \& $11.1 \%$ strongly disagree, undecided and agree respectively in the study area. Table 4 shows that $45.5 \%$ of the respondents agree that income determine the level of consuming snail while $7.1 \%, 11.1 \%$, $19.2 \%$ and $17.2 \%$ were strongly disagree, disagree, undecided and strongly agree. From the result obtained it was also revealed that $33.3 \%$ of the respondents were undecided that they can afford the price to buy snail followed by $25.3 \%$ of disagree while 
$22.2 \%, 23.1 \%$ and $6.1 \%$ were agree, strongly agree and strongly disagree respectively. The result also shows the taste of the snail affect the rate of consumption of the respondents were mostly agree by $24.2 \%$ while $14.1 \%, 21.2 \%, 19.2 \%$ and $21.2 \%$ were strongly disagree, disagree, undecided and strongly disagree respectively. The result further shows that $57.6 \%$ of respondents strongly disagree that snail are not readily available while $36.4 \%$ and $6.1 \%$ were disagree and undecided respectively in the study area. Lastly, the study also shows that that $52.5 \%$ of respondents strongly disagree that their religion does not permit snail consumption while the other $36.4 \%$, $5.1 \%, 5.1 \%$ and $1.0 \%$ were disagree, undecided, strongly agree and agree respectively in the study area. The regression on consumption of snail meat revealed that Age and Health of the respondents were significant at $5 \%$ and $10 \%$ level, though has a positive relationship to the rate at which the household consume snail in the study area, this implies that as the Health and Age of the respondents increases there is a probability that the rate at which the snail is consumed will increased.

Table 5: Factors that determine snail meat consumption

\begin{tabular}{llll}
\hline Model & Coefficient & Std error & T-value \\
Constant & 5.149 & 0.603 & 8.541 \\
X1 Family size & 0.034 & 0.160 & 0.210 \\
X2 Education & 0.024 & 0.080 & 0.295 \\
X3Religion & -0.178 & 0.116 & -1.530 \\
X4 Age & $0.195^{* *}$ & 0.093 & 2.101 \\
X5 Price & 0.019 & 0.080 & 0.235 \\
X6 Health & $0.308^{*}$ & 0.175 & 1.75 \\
\hline uthor computation, 2019. Note: $(*)=10 \%$ and $(* *)=5 \%$ level of \\
\multicolumn{4}{c}{ significant }
\end{tabular}

From the research, it is concluded that $43.4 \%$ of the respondents were male while $56.6 \%$ were female which implies that female were more than male, it also indicate that $44.4 \%$ of the respondents fall between the age of $31-40$ and $59.6 \%$ were married and $53.5 \%$ of the household have the largest size, it also implies that $34.3 \%$ had secondary education, snail meat are not affected in consumption by religion belief.Based on the research $43.4 \%$ of the respondents agree that snail meat reduce obesity of the body and $35.4 \%$ strongly agree that snail meat can cure cancer.Lastly it was concluded that income, price, taste, Availability and Accessibility are the factor affecting snail activities and consumption in Ibarapa Central Local government, Oyo-state).

Conclusion: Based on the findings and results obtained from this work, it is recommended thatSnail meat should be introduced to the household diet because ofits medicinal value. Awareness should be created among dwellers about the nutritional and medicinal values derivable in the consumption of snail meat. Farm settlements for heliculture may be established through public and private partnerships means of creating meaningful employment.

\section{REFERENCES}

Adeyeye, E 1996: International journal of food science and Nutrition 42(2): 111-116.

Adeniyi, B, Shobonke, IA, Omotosho, AB. (2013) Economic analysis of snail meat consumption in Ibarapa local Government Area of Oyo state. $J$. Mkt. Res. s2:16-21,

Adeniyi, JP (2008): "Fish consumption in Nigeria" implication for fisheries Development policies. $J$. West Afr. Fish. Soc. Nig. 5:12-20

Agbelusi, EA, Ejide, BN. (1992). Utilization of the African giant land snail (Archachatina marginata) in the humid areas of Nigeria. Trop. Agric. 69:6772

Agbogidi, OM, Okonta, BC, Ezean, EL, (2008). $J$. Agric. Biol. Sci. 3(3): 26-29.

Akinnusi, O (2000). Snail rearing. Case study of Abeokuta, Ogun State, Nigeria. Proceedings of the $5^{\text {th }}$ Annual Conference of Animal Science Association of Nigeria. Held in Port Harcourt, Nigeria.

Akinnusi, FAO, Adeoye AS, Bello, TT, Ajuwon, AO (2018). Comparative growth and feed intake analyze of Albino and Normal skinned Giant land snail (Archachatina marginata) during dry season. J. Molluscan Res. 4:17-24,

Akinnusi: PAO, Oni, OO, Ademolu, KO. (2018) Heamolymph biochemical properties of Giant African Land Snail (Archachatina marginata) from south west Nigeria. J. Mollusca Res. 4:4044 ,

Amusan, AJ; Omole, AJ. (2000). A paper presented on learning and sharing on snail farming management, organized by UFID's, capacity building for decentralized development on $5^{\text {th }}$ $7^{\text {th }}$ July, 2002 at I. A. R. \& T., Ibadan.

Ayodele, IA Ashimolowo, AA (1999). Essential of snail farming. Agape prints, Ibadan guide. Technical bulletin, I. A. R. \& T., Ibadan.Pp29

Babara,L (2013). Florida buttles slimy invasion by giant snails Pp 23. 
Bright, SO (1999). Prospects and problems associated with snail farming. Heritage Printers Nigeria Limited, Lagos. Page 96

Cobbinah, JR (1993). Snail farming in West Africa. A practical guide CTA publication. Sayce Publishing. United Kingdom.

Cobbinah JR. and Ben O. (2008): Snail Farming: Production, processing and marketing. Agrodokseries No. 47 Pp6.

Ejidike, BN, Oyekunle. OO (2019). Survival and growth performance of African Land Snail Juvenile Reared on different soil types proceeding of $27^{\text {th }}$ annual conference of the NNSAP held in AkurePp 307-310.

Eze, CC, Ohakenya, DO; Oguoma, NNO (2000). Analysis of land snail marketing in Owerri Agricultural Zone of Imo State, Nigeria. Animal Production Research Advances Journal Vol. 2(2) pages $94-97$

F AO. (2013). Food and Agricultural Organization Production Year Book, Rome Italy.9

Funmilayo, SM. (2008): Preliminary in vegetation of the growth and performance of Giant Land Snail (Archachatina marginata) fed with selected household wastes. Afr. J. Agric. Res. 3(9): 647649.

Goodman, AK. (2008): Giant African Land Snails property pp 12

Hackett, Rosalind IJ (1988). "The Academic Study of Religion in Nigeria pp20

Imevbore, EA Ademosun, AA. (1988). the nutritive value of the African giant land snail. Journal of Animal Production Resource (8) 2: 76 - 78. Nigeria

Kehinde, AS (2009) Utilization of cassava by products by African land snail (Archachatina marginata, Swainson) $\mathrm{PhD}$ Thesis Submitted at the department of Animal Science, University of Ibadan pp1-8, 2009
Kehinde, AS; Babatunde, TO; Kehinde, OJ (2019); Lifecycle Evaluation of the Nutritional Benefits and Biosafety of Snail (Archachatina marginata).J. Exp. Agric. Inter. 40(5). 1-7

Malik, AA; Aremu A, Bayode GB Ibrahim BA. (2011): A nutritional organoleptic assessment of the meat of the giant African land snail (archachatina marginataswaison) compared to the meat of other livestock Ppt. marginata). M.Sc thesis, University of Ibadan (unpublished) Pp 56.

Mulero,B.I (211): Partial replacement of groundnut cake with Moringaoleifera and Telfairia occidentalis supplyment on African Giant Land Snails (Archachatina Achatina Linne) Technical report $\mathrm{Pp} 10$.

Oddian, SO (2002): Characteristics of growth of edible Giant Land Snail (Archachatina Marginata) pp20

Odukoya, AA (1998). Comparative effect of four different leave on the growth performance of grower snails (Archachatinamarginata). M. Sc., Thesis, University of Ibadan, Nigeria.

Omole, AJ (2002). Nutrient requirements for different stages of growth of African giant snail (Archachatina marginata). Ph. D. Thesis, submitted at the department of Animal Science, University of Ibadan. Page 2

Oropo, AO Olabode, OA, Akeredolu, EO Ademolu KO.(2019) Effect of different light regimes on nutritional and Haemollph biochemical values of Giant African Land Snail (Archachatina marginata). J. Mollusca Res. 5:4-9 